\title{
PODELITEV PRIZNANI \\ IZOBRAŽEVALNI MANAGEMENT 2002 - TOP 10 Primerjalna analiza
}

Upravljati podjetje $\mathrm{z}$ delavci znanja in to prav v času eksplozije znanja ni prav lahka naloga. Prav tako je zahtevno ustvarjanje okolja, ki spodbuja in nagrajuje prenašanje ter uporabo znanja. Spodbujanje kreativnosti in iskanje novih uporabnih znanj je še težja naloga. Za učeča se podjetja, ki želijo ostati na vrhu, pa to ni le prednostna naloga, ampak tudi središče korporacijskega komuniciranja.

$S$ temi besedami se je začela podelitev priznanj TOP 10 - IZOBRAŽEVALNI MANAGEMENT 2002, ki jih je Inštitut Sofos podelil v okviru konference GV Izobraževalni management 21. novembra letos v Ljubljani.

Namen akcije TOP 10 ni bil, da bi iskali in našli enega, absolutnega zmagovalca, ampak je organizatorje vodil cilj najti več zmagovalcev, torej tistih slovenskih podjetij, ki

- izkazujejo neposredno povezanost izobraževalne in poslovne strategije,

- sistematično pridobivajo nova znanja,

- omogočajo zaposlenim preizkušanje in širjenje novo pridobljenega znanja in

- skrbijo za izobraževanje slehernega zaposlenega

ter nam s takšnimi načini ravnanja $\mathrm{z}$ zaposlenimi utirajo pot v ekonomijo znanja.

"Cilj akcije bo v celoti uresničen in izpolnjen šele takrat, ko se bomo začeli vsi zgledovati po najboljših in se učiti od njih", je še dodala moderatorka podelitve.

GV Izobraževanje je v sodelovanju z Inštitutom Sofos že avgusta pripravilo poseben nominacijski obrazec, s pomočjo katerega so lahko podjetja kandidirala za priznanje TOP 10. Na razpis se je prvo leto akcije prijavilo 26 slovenskih podjetij, ki so odgovarjali na osem kvantitativnih in osem kvalitativnih vprašanj v zvezi z vlaganjem v izobraževanje in skrbjo za razvoj zaposlenih.

Vsi, ki so sodelovali na razpisu - pa čeprav se niso uvrstili med nagrajence -, so s tem dejanjem veliko prispevali $\mathrm{k}$ razvoju izobraževalnega menedžmenta v Sloveniji, saj smo na podlagi zbranih podatkov lahko pripravili primerjalno analizo o upravljanju in poslovodenju znanja - prvo tovrstno v Sloveniji. Del rezultatov navajamo v nadaljevanju, sicer pa celotna analiza med seboj primerja 24 parametrov.

\section{PRIMERIALNA ANALIZA ("BENCHMARKING") PODJETIJ, UVRŠČENIH V IZBOR IZOBRAŽEVALNI MANAGEMENT 2002 - TOP 10}

Za opravljeno analizo si želimo, da bi služila kot model dobre prakse upravljanja z znanjem za vsa slovenska podjetja. Hkrati smo s tem postavili temelje za ugotavljanje in merjenje napredka $v$ prihodnosti. Že naslednje leto bomo namreč lahko rezultate primerjali. 
Prav tako pa nam bodo rezultati lahko v pomoč pri prizadevanjih za uveljavitev standardov na področju izobraževanja in usposabljanja. Če standardi tako ali drugače krojijo organizacijsko življenje, zakaj ne bi standardizirali tudi tako pomembnega področja kot je razvoj zaposlenih. Slednjo misel podpira tudi standard Vlagatelji v ljudi, za katerega prav sedaj potekajo zelo intenzivna prizadevanja za uveljavitev v slovenskem prostoru.

mag. Daniela Brečko

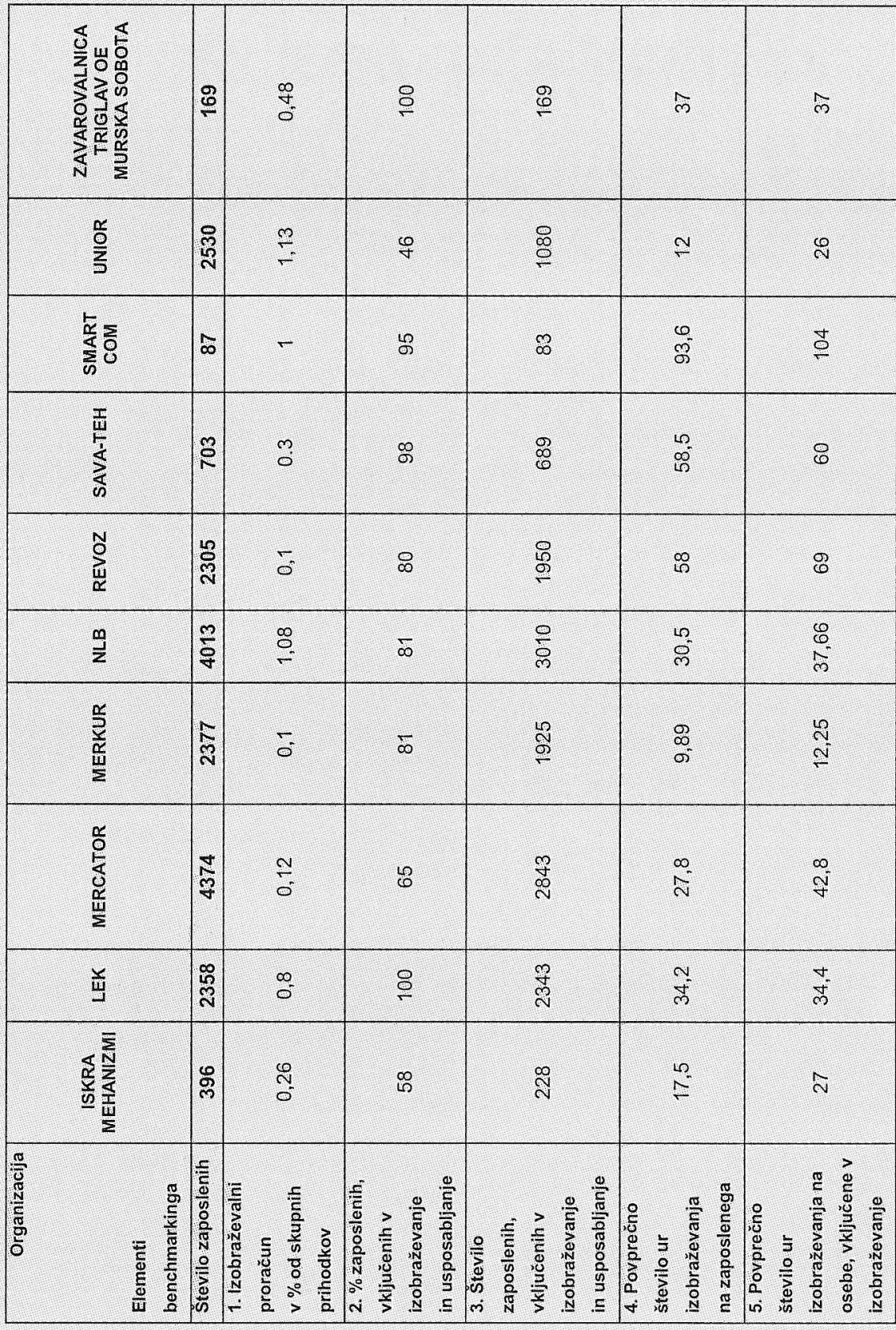

